\title{
Comparison of efficacy and safety of topical luliconazole with topical fluconazole against tinea corporis in a tertiary care hospital
}

\author{
E. Seshathri*, R. Deepthi Krishna
}

Department of Pharmacology, Karpaga Vinayaga Institute of Medical Sciences and Research Centre, Maduranthakam, Chengalpattu, Tamil Nadu, India

Received: 02 June 2021

Accepted: 17 June 2021

*Correspondence:

Dr. E. Seshathri,

Email: sesha2009@gmail.com

Copyright: $@$ the author(s), publisher and licensee Medip Academy. This is an open-access article distributed under the terms of the Creative Commons Attribution Non-Commercial License, which permits unrestricted non-commercial use, distribution, and reproduction in any medium, provided the original work is properly cited.

\section{ABSTRACT}

Background: Dermatophytosis is a common cutaneous infection worldwide with prevalence varying from $20 \%$ to $25 \%$. Luliconazole is a newer topical antifungal applied once daily with greater reservoir property in stratum corneum. Objective of the study was to compare the clinical efficacy and safety of luliconazole $1 \%$ cream with Fluconazole $1 \%$ cream in patients with mild to severe grades of tinea corporis.

Methods: A total of 100 patients with mycologically confirmed tinea corporis were randomised into group A and B respectively. Group A, 50 patients received luliconazole $1 \%$ for 2 weeks and group B, 50 patients received fluconazole $1 \%$ cream for 4 weeks. Patients were clinically and mycologically evaluated on $0,2^{\text {nd }}$ and $4^{\text {th }}$ week of treatment and followed up on $8^{\text {th }}$ week for any relapse.

Results: Significant improvement in efficacy was seen in Luliconazole while compared with fluconazole group against tinea corporis infection. Mycological cure and clinical improvement showed significant difference in group A. The safety and tolerability profile of both groups were good and statistically comparable.

Conclusions: Luliconazole $1 \%$ cream is found to be safe, effective and tolerable with low incidence of relapse than fluconazole $1 \%$ cream.

Keywords: Luliconazole, Fluconazole, Tinea corporis, Topical cream

\section{INTRODUCTION}

Tinea corporis is a most common superficial dermatophytosis infection in the skin. Dermatophytes are fungi which are capable of causing skin changes known as ringworm or dermatophytosis. Microsporum, Trichophyton and Epidermophyton are moulds belonging to ringworm species. ${ }^{1}$ Dermatophytosis is a common cutaneous infection worldwide with prevalence varying from twenty percentage to twenty five percentage which includes all tinea infections. ${ }^{2}$ A clinical survey conducted by world health organisation on the prevalence of dermatophytic infection has shown that twenty percentage of people presenting for clinical advice are suffering from cutaneous fungal infections worldwide. ${ }^{3}$
Tinea corporis occurs anywhere in the body except the scalp, beard, feet, or hands. They present as an annular plaque with a slightly raised and often scaly with advancing border. Each lesion may have one or several concentric rings with red papules or plagues in the centre. As the infection progresses, the centre may clear, leaving post-inflammatory hypo or hyper pigmentation. ${ }^{4}$

Topical and systemic therapies are being used to treat dermatophytic infections. Topical therapy is generally effective for uncomplicated Tinea corporis of small areas and short duration of treatment. ${ }^{5}$ Topical agents like Allylamine and Imidazole group for superficial fungal infections have broad-spectrum activity, high mycological cure rate, convenient dosing, and low incidence of side effects. $^{6}$ 
Imidazole selectively inhibits fungal cytochrome P450 (CYP450) $14 \alpha$-demethylase enzymes, which disrupts the conversion of lanosterol to ergosterol and contribute to the deterioration of subcellular organelles and to cell death. ${ }^{7}$ The imidazole antifungal agent fluconazole has been widely used topically for treatment of superficial dermatophytosis for long time. However, fluconazole has some limitations like fungal resistance and long duration of treatment, which can contribute to patient non adherence, and disease recurrence. ${ }^{8}$

Luliconazole is a novel imidazole anti-fungal drug, which exhibits a broad spectrum of activity against dermatophytes, yeasts and dimorphic fungi. ${ }^{9}$ Topical application of luliconazole was well tolerated by the patients with mild or insignificant adverse drug reaction and showed high cure rate with reduced recurrence in short duration of treatment. Hence, this study aimed to assess the efficacy and safety of topical luliconazole $1 \%$ cream with topical fluconazole $1 \%$ cream in with mild to severe grades of tinea corporis patients.

\section{METHODS}

An open-label, prospective, randomized and comparative study was conducted in department of dermatology in Karpaga Vinayaga institute of medical sciences and research centre after obtaining institutional ethics committee approval (IEC reference No: 48/2020). Patients confirmed with clinical and positive result of $\mathrm{KOH}$ test for tinea corporis infections with age group between 18-40 years of either sex were included for the study. Patients with clinical diagnosis of tinea pedis/Manum, received topical or oral anti-mycotic either 1 or 4 weeks prior to the initiation of the study, history of hypersensitivity to study drugs, immunocompromised individuals, Patients with superadded bacterial infection, diabetes mellitus, collagen diseases, auto-immune diseases were excluded from the study.

During the period of July 2020 to December 2020, 212 participants with Tinea corporis were screened by obtaining medical history, clinical examination and microscopic confirmation using $10 \% \mathrm{KOH}$ for determination of fungal element. Out of 212 patients, 100 were recruited and randomly divided into two groups by simple randomization. i.e., Group A (50 patients) were instructed to apply luliconazole $1 \%$ cream once daily for two weeks, group B (50 patients) were instructed to apply fluconazole $1 \%$ cream once daily for four weeks. Patients were instructed to apply the cream on the affected area once daily and advised to discontinue application if they develop any adverse effects and to report.

At start of treatment, $2^{\text {nd }}, 4^{\text {th }}$ and $8^{\text {th }}$ week, symptoms and signs like itching, erythema and scaling were assessed on pre-determined 4-point scale as: absent (0), mild (1), moderate (2) and severe (3) depending upon intensity. Mycological cure rate was studied by performing $10 \%$ $\mathrm{KOH}$ at each visit to evaluate the rate of improvement in study participants. Statistical analysis was done with the help of Graph Pad prism instat version 3 (USA). Basic statistical evaluation including mean and standard deviation (SD) was calculated using Chi-square and t test.

\section{RESULTS}

Out of 212 screened patients, 112 were excluded and 100 were enrolled for the study based on the inclusion and exclusion criteria. The reasons for exclusion were: Patients with diabetes mellitus (31), auto-immune disease (33), malignant disease (09), cardiac problems (30) and patients age below 14 years (09).

The study participants were randomized into 2 groups, with group A (50 patients receiving luliconazole $1 \%$ cream once daily for 2 weeks and group B (50 patients) receiving fluconazole $1 \%$ cream once daily for 4 weeks. In group A, 3 participants and in group B, 2 participants were withdrawn from the study due to nature of their work. Three participants from group A and 2 participants from group B were failed to follow up due to personal reason. At the outset, in group A 44 patients and group B 46 patients completed the study. The demographic profiles of the patients enrolled in the study are shown in Table 1 . The mean age in group A was 28.87 \pm 9.78 and $31.61 \pm 11.43$ in group B.

Table 1: Baseline demographic profiles in the two groups.

\begin{tabular}{|l|l|l|}
\hline Parameter & $\begin{array}{l}\text { Group A, } \\
\text { Luliconazole, } \\
(\mathbf{n = 5 0})\end{array}$ & $\begin{array}{l}\text { Group B, } \\
\text { Fluconazole, } \\
(\mathbf{n = 5 0})\end{array}$ \\
\hline Patients & 50 & 50 \\
\hline Age (Years) & $28.87 \pm 9.78$ & $31.61 \pm 11.43$ \\
\hline Male:Female & $31: 19$ & $27: 23$ \\
\hline Weight $(\mathbf{k g})$ & $63.8 \pm 8.28$ & $64.6 \pm 12.23$ \\
\hline Height $(\mathbf{c m})$ & $158.9 \pm 8.4$ & $163.3 \pm 13.28$ \\
\hline
\end{tabular}

All the participants in each group were evaluated clinically at $2^{\text {nd }}, 4^{\text {th }}$ and $8^{\text {th }}$ week for symptoms and signs like itching, erythema and scaling were assessed on pre-determined 4point scale as: absent (0), mild (1), moderate (2) and severe (3) depending upon intensity. Mycological cure rate was studied by performing $10 \% \mathrm{KOH}$ at each visit to evaluate the rate of improvement in study participants. Primary efficacy was the improvement in the signs and symptoms and inference from $\mathrm{KOH}$ mount at $2^{\text {nd }}$ and $4^{\text {th }}$ week.

In group A, itching subsided in 83.1 and $91.5 \%$ of patients, erythema was absent in 97.6 and $97.6 \%$ of patients and scaling subsided in 87.2 and $95.5 \%$ of patients on $2^{\text {nd }}$ and $4^{\text {th }}$ week respectively. In group B, itching subsided in 58.3 and $60.4 \%$ of patients, erythema was absent in 27.1 and $35.4 \%$ of patients, scaling subsided in $56.3 \%$ and $62.5 \%$ of patients on $2^{\text {nd }}$ and $4^{\text {th }}$ week respectively. After treatment group A showed significant difference in erythema and scaling at $4^{\text {th }}$ week of treatment with $\mathrm{p}=0.05$ (Table 2 ). 
Table 2: Serial change in the distribution of efficacy of parameters in the two treatment groups at different points of the time.

\begin{tabular}{|c|c|c|c|c|c|c|c|c|c|}
\hline \multirow[b]{2}{*}{$\begin{array}{l}\text { Clinical } \\
\text { parameters }\end{array}$} & \multicolumn{4}{|c|}{ Luliconazole } & \multicolumn{4}{|c|}{ Fluconazole } & \multirow[b]{2}{*}{ P value } \\
\hline & $\begin{array}{l}\text { Baseline } \\
(\mathbf{n}=50) \\
(\%)\end{array}$ & $\begin{array}{l}2^{\text {nd }} \text { week } \\
(n=47) \\
(\%)\end{array}$ & $\begin{array}{l}4^{\text {th }} \text { week } \\
(n=47) \\
(\%)\end{array}$ & $\begin{array}{l}8^{\text {th }} \text { week } \\
(n=44) \\
(\%)\end{array}$ & $\begin{array}{l}\text { Baseline } \\
(\mathbf{n}=\mathbf{5 0}) \\
(\%)\end{array}$ & $\begin{array}{l}2^{\text {nd }} \text { week } \\
(n=48) \\
(\%)\end{array}$ & $\begin{array}{l}4^{\text {th }} \text { week } \\
(n=48) \\
(\%)\end{array}$ & $\begin{array}{l}8^{\text {th }} \text { week } \\
(n=46) \\
(\%)\end{array}$ & \\
\hline \multirow{3}{*}{ Itching } & Mild-14 & $\begin{array}{l}\text { No improved-1 } \\
(2.1)\end{array}$ & $\begin{array}{l}\text { No } \\
\text { improved-0 }\end{array}$ & $\begin{array}{l}\text { No improved- } \\
1(2.3)\end{array}$ & Mild-17 & $\begin{array}{l}\text { No improved-8 } \\
\text { (16.7) }\end{array}$ & $\begin{array}{l}\text { No improved-3 } \\
(6.3)\end{array}$ & $\begin{array}{l}\text { No improved-3 } \\
(6.5)\end{array}$ & 0.24 (Day 0) \\
\hline & $\begin{array}{l}\text { Moderate- } \\
25\end{array}$ & $\begin{array}{l}\text { Improved- } 7 \\
(14.9),\end{array}$ & $\begin{array}{l}\text { Improved-9 } \\
\text { (19.1) }\end{array}$ & $\begin{array}{l}\text { Improved-2 } \\
(4.5)\end{array}$ & $\begin{array}{l}\text { Moderate- } \\
27\end{array}$ & $\begin{array}{l}\text { Improved-12 } \\
(25)\end{array}$ & $\begin{array}{l}\text { Improved-13 } \\
\text { (27) }\end{array}$ & $\begin{array}{l}\text { Improved-5 } \\
(10.9)\end{array}$ & 0.75 (Day 14) \\
\hline & Severe-11 & $\begin{array}{l}\text { Subsided-39 } \\
(83.1)\end{array}$ & $\begin{array}{l}\text { Subsided- } \\
43(91.5)\end{array}$ & $\begin{array}{l}\text { Subsided-41 } \\
(93.2)\end{array}$ & Severe-6 & $\begin{array}{l}\text { Subsided-28 } \\
(58.3)\end{array}$ & $\begin{array}{l}\text { Subsided- } \\
29(60.4)\end{array}$ & $\begin{array}{l}\text { Subsided-38 } \\
(82.6)\end{array}$ & 0.92 (Day 28) \\
\hline \multirow{3}{*}{ Erythema } & Mild-24 & $\begin{array}{l}\text { No improved-2 } \\
(4.3)\end{array}$ & $\begin{array}{l}\text { No } \\
\text { improved-2 } \\
(4.3)\end{array}$ & $\begin{array}{l}\text { No improved- } \\
2(4.5)\end{array}$ & Mild-6 & $\begin{array}{l}\text { No improved-7 } \\
(14.6)\end{array}$ & $\begin{array}{l}\text { No improved-6 } \\
(12.5)\end{array}$ & $\begin{array}{l}\text { No improved-5 } \\
(10.9)\end{array}$ & 0.13 (Day 0) \\
\hline & $\begin{array}{l}\text { Moderate- } \\
20\end{array}$ & $\begin{array}{l}\text { Improved-5 } \\
(10.6)\end{array}$ & $\begin{array}{l}\text { Improved-5 } \\
\text { (10.6) }\end{array}$ & $\begin{array}{l}\text { Improved-1 } \\
\text { (2.3) }\end{array}$ & $\begin{array}{l}\text { Moderate- } \\
27\end{array}$ & $\begin{array}{l}\text { Improved-28 } \\
(58.3)\end{array}$ & $\begin{array}{l}\text { Improved-33 } \\
(68.8)\end{array}$ & $\begin{array}{l}\text { Improved-17 } \\
(37.1)\end{array}$ & 0.05 (Day 14) \\
\hline & Severe -6 & $\begin{array}{l}\text { Subsided-40 } \\
(97.6)\end{array}$ & $\begin{array}{l}\text { Subsided-40 } \\
(97.6)\end{array}$ & $\begin{array}{l}\text { Subsided-41 } \\
(93.2)\end{array}$ & Severe-17 & $\begin{array}{l}\text { Subsided-13 } \\
\text { (27.1) }\end{array}$ & $\begin{array}{l}\text { Subsided-17 } \\
(35.4)\end{array}$ & $\begin{array}{l}\text { Subsided-24 } \\
(52.2)\end{array}$ & 0.06 (Day 28) \\
\hline \multirow{3}{*}{ Scaling } & Mild- 37 & $\begin{array}{l}\text { No improved -3 } \\
(6.4)\end{array}$ & $\begin{array}{l}\text { No } \\
\text { improved-2 } \\
(8.7)\end{array}$ & $\begin{array}{l}\text { No improved- } \\
1(2.3)\end{array}$ & Mild-35 & $\begin{array}{l}\text { No improved-3 } \\
(6.3)\end{array}$ & $\begin{array}{l}\text { No Imp- } 4 \\
(8.7)\end{array}$ & $\begin{array}{l}\text { No improved-4 } \\
(8.7)\end{array}$ & 0.33 (Day 0) \\
\hline & $\begin{array}{l}\text { Moderate- } \\
12\end{array}$ & $\begin{array}{l}\text { Improved-3 } \\
(6.4)\end{array}$ & $\begin{array}{l}\text { Improved-4 } \\
(8.5)\end{array}$ & $\begin{array}{l}\text { Improved-1 } \\
\text { (2.3) }\end{array}$ & $\begin{array}{l}\text { Moderate- } \\
10\end{array}$ & $\begin{array}{l}\text { Improved-18 } \\
(37.5)\end{array}$ & $\begin{array}{l}\text { Improved- } \\
12(25)\end{array}$ & $\begin{array}{l}\text { Improved-8 } \\
(17.4)\end{array}$ & 0.05 (Day 14) \\
\hline & Severe-1 & $\begin{array}{l}\text { Subsided-41 } \\
(87.2)\end{array}$ & $\begin{array}{l}\text { Subsided-42 } \\
(95.5)\end{array}$ & $\begin{array}{l}\text { Subsided-42 } \\
(95.5)\end{array}$ & Severe-5 & $\begin{array}{l}\text { Subsided-27 } \\
(56.3)\end{array}$ & $\begin{array}{l}\text { Subsided- } \\
30(62.5)\end{array}$ & $\begin{array}{l}\text { Subsided-34 } \\
\text { (73.9) }\end{array}$ & 0.05 (Day 28) \\
\hline $\begin{array}{l}\text { Skin } \\
\text { scraping } \\
\text { for fungus } \\
\text { positive }\end{array}$ & All & $13(27.7)$ & $10(21.3)$ & $9(20.5)$ & All & $19(39.5)$ & $10(20.8)$ & $14(30.4)$ & $\begin{array}{l}0.59 \text { (Day 14) } \\
0.84 \text { (Day 28) }\end{array}$ \\
\hline
\end{tabular}

Table 3: Assessment of patient compliance, relapse rate and adverse drug reaction report.

\begin{tabular}{|llll|}
\hline Parameter & Luliconazole, $(\mathbf{n}=\mathbf{5 0})(\boldsymbol{\%})$ & Fluconazole, $(\mathbf{n = 5 0})(\boldsymbol{\%})$ & $\mathbf{7 9}$ \\
\hline Patient compliance & 92 & 0.14 \\
\hline Relapse rate & 4 & 20 & 0.73 \\
\hline ADR & 2 & 8 & 0.95 \\
\hline
\end{tabular}


At the follow up period of $8^{\text {th }}$ week most of the infections due to tinea corporis subsided or was being equivalent with $4^{\text {th }}$ week in both the groups. In group A itching, erythema and scaling were subsided by $93.2 \%, 93.2 \%$ and $95.5 \%$ respectively. Similarly in group B itching, erythema and scaling subsided by $82.6 \%, 52.2 \%$ and $73.9 \%$ respectively.

Both the drugs provided effective relief in signs and symptoms against tinea corporis patients in between the groups. Moreover, luliconazole achieved better relief of signs and symptoms on $4^{\text {th }}$ week $(94.8 \%)$ while compared with fluconazole $(52.7 \%)$. Skin scrapings were done for all the study participants in each visit for fungal elements in both the groups. After 2 weeks of treatment with luliconazole, skin smear was positive in $13(27.7 \%)$ patients; thus, a mycological cure of $72.3 \%$ was achieved. On $4^{\text {th }}$ and $8^{\text {th }}$ week skin smear was positive in $19(39.5 \%)$ and $9(20.5 \%)$ patients and the cure rate reached $80.2 \%$ and $79.5 \%$ respectively.

In fluconazole group, mycological cure rate was $60.5 \%$ in $2^{\text {nd }}$ week, $65.3 \%$ in $4^{\text {th }}$ week and $69.6 \%$ on $8^{\text {th }}$ week, which was lower when compared with luliconazole (Table 2).
Overall, patient's compliance was high in luliconazole group (92\%) while compared to fluconazole group (79\%). Moreover, the occurrence of relapse rate $(4 \%)$ was very low in luliconazole treated patients compared to fluconazole $(20 \%)$ treated patients. Only $2 \%$ of patients reported with hypersensitivity as a component of ADR in luliconazole group, where as in fluconazole it was little high $(8 \%)$ (Table 3$)$. The frequency and occurrence of various ADR was showed in Table 4.

Patients treated with luliconazole group achieved therapeutic improvement among 44 participants (93.6\%) at $2^{\text {nd }}$ week of therapy. Similarly, $45(95.8 \%)$ and 43 $(97.7 \%)$ participants showed best improvement at $4^{\text {th }}$ and $8^{\text {th }}$ weeks of therapy respectively (Table 5). Patients treated with fluconazole group showed therapeutic improvement in 40 participants $(83.3 \%)$ at $2^{\text {nd }}$ week of therapy. Similarly, $42(87.5 \%)$ and $44(95.6 \%)$ participants showed best improvement at $4^{\text {th }}$ and $8^{\text {th }}$ weeks of therapy respectively (Table 6). The luliconazole treated patients showed significant difference in improvement while compared to fluconazole treated group at $2^{\text {nd }}$ and $4^{\text {th }}$ week with better patient compliance.

Table 4: The frequency of various adverse drug reactions between the study groups.

\begin{tabular}{|lllll|}
\hline Adverse drug reaction & Luliconazole, $(\mathbf{n}=\mathbf{4 4})$ & Percent $(\boldsymbol{\%})$ & Fluconazole, $(\mathbf{n}=\mathbf{4 6})$ & Percent $(\boldsymbol{\%})$ \\
\hline Redness & - & 0 & 1 & 2 \\
\hline Swelling & - & 0 & - & 0 \\
\hline Stinging sensation & 2 & 4 & 4 & 8 \\
\hline Hypersensitivity & 1 & 2 & - & 0 \\
\hline Skin irritation & - & 0 & - & 0 \\
\hline Itching & 1 & 2 & 1 & 2 \\
\hline Skin rash & - & 0 & 1 & 2 \\
\hline
\end{tabular}

Table 5: The effects of treatment of luliconazole at different points of the time.

\begin{tabular}{|c|c|c|c|c|c|c|c|}
\hline \multirow{2}{*}{ Therapeutic effect } & \multicolumn{2}{|l|}{$2^{\text {nd }}$ week, $(n=47)$} & \multicolumn{2}{|l|}{$4^{\text {th }}$ week, $(n=47)$} & \multicolumn{2}{|l|}{$8^{\text {th }}$ week, $(n=44)$} & \multirow{2}{*}{ P value } \\
\hline & Total numbers & $\%$ & Total numbers & $\%$ & Total numbers & $\%$ & \\
\hline Improvement & 44 & 93.6 & 45 & 95.8 & 43 & 97.7 & 0.89 \\
\hline No improvement & 3 & 6.3 & 2 & 4.3 & 1 & 2.3 & 0.17 \\
\hline
\end{tabular}

Table 6: The effects of treatment of fluconazole at different points of the time.

\begin{tabular}{|c|c|c|c|c|c|c|c|}
\hline \multirow{2}{*}{ Therapeutic effect } & \multicolumn{2}{|l|}{$2^{\text {nd }}$ week, $(n=48)$} & \multicolumn{2}{|l|}{$4^{\text {th }}$ week, $(n=48)$} & \multicolumn{2}{|l|}{$8^{\text {th }}$ week, $(n=46)$} & \multirow{2}{*}{ P value } \\
\hline & Total numbers & $\%$ & Total numbers & $\%$ & Total numbers & $\%$ & \\
\hline Improvement & 40 & 83.3 & 42 & 87.5 & 44 & 95.6 & 0.72 \\
\hline No improvement & 8 & 16.6 & 6 & 12.5 & 2 & 4.3 & 0.34 \\
\hline
\end{tabular}

\section{DISCUSSION}

Tinea corporis is a common form of superficial fungal infection, in general it is known as "Ringworm". Dermatophytes are fungi that infect epidermis of the skin, hair and nail due to colonization in keratinized layers. ${ }^{10} \mathrm{In}$ general, dermatophytes may produce mild to chronic lesions based on the site of disease exist in our body. The degree of inflammatory response depends in part on the site of infection and the immune of the host. The dermatophytes are restricted to the keratinized tissues although inflammation involves the dermis and Malpighian stratum of epidermis. The most common dermatophytes that cause tinea corporis are T. rubrum, $T$. mentagrophytes, M. canis, T. tonsurans. ${ }^{8}$ Appropriate treatment of dermatophytosis is of utmost importance as persistent infections can compromise the quality of life to a remarkable extent. Both topical and systemic therapies are used to treat dermatophyte infections depending upon 
the site involved and type and extent of infection. ${ }^{9}$ Topical therapy is effective for uncomplicated tinea corporis of mild to moderate grades. Topical agents used in these infections are the imidazole, allylamines, tolnaftate and ciclopirox. Clotrimazole, an imidazole anti-fungal has been widely used topically for treatment of superficial dermatophytosis for a considerable period of time. ${ }^{11}$

Luliconazole (LLCZ) is a newer imidazole anti-fungal agent with broad-spectrum antifungal activity that is structurally related to its predecessor, lanoconazole. LLCZ, lanoconazole and efinaconazole have been clinically used as topical drugs in the treatment of onychomycosis and dermatophytosis. ${ }^{12}$ These drugs are also known to be highly active against dermatophytes. There is as yet no report of resistance to this drug. So, we have selected this drug to compare the efficacy and safety of topical fluconazole $1 \%$ cream, which is a comparatively new drug for topical use in uncomplicated cases of tinea corporis infection. ${ }^{13}$

Fluconazole is a triazole antifungal with similar mechanism of action as clotrimazole, an imidazole. Both inhibit sterol $14 \alpha$-demethylase, a microsomal cytochrome P450 enzyme in fungi. ${ }^{14}$ Thus, there is impairment of ergosterol biosynthesis for the cytoplasmic membrane and accumulation of $14 \alpha$-methyl sterols. This leads to disruption of enzyme systems and electron transport system within the fungus. Topical fluconazole has shown to be effective and safe in superficial dermatomycosis. ${ }^{15}$

Subhash et al studied luliconazole is an imidazole antifungal agent with unique structure, as the imidazole moiety is incorporated into the ketone dithioacetate structure. Luliconazole is the R-enantiomer, and has more potent anti-fungal activity than lanoconazole. ${ }^{15}$ The strong clinical antifungal activity of luliconazole is possibly attributable to a combination of strong in vitro antifungal activity and favourable pharmacokinetics properties in the skin. ${ }^{16}$

This present study compared the efficacy and safety of topical luliconazole in cases of mild to moderate grades of Tinea corporis to the conventional topical preparation of fluconazole. The results show that both the drugs are equally effective in bringing about clinical cure and relief of symptoms. Significant difference in erythema and scaling between the two groups at $2^{\text {nd }}$ and $4^{\text {th }}$ week of treatment with $\mathrm{p}=0.05$. Moreover, luliconazole has showed good relief in signs and symptoms on $2^{\text {nd }}$ week itself, the infections underwent complete clearance utmost $95.5 \%$ on $2^{\text {nd }}$ week itself.

The mycological cure rate does not show any significance between the 2 groups. With luliconazole mycological cure rate achieved $79.5 \%$ on $8^{\text {th }}$ week. With fluconazole, the mycological cure rate was $69.6 \%$ on $8^{\text {th }}$ week. Similarly, only $2 \%$ of patients reported hypersensitivity as a component of ADR in luliconazole group, where as in fluconazole it was little high (8\%).
In general, patient's compliance was high in luliconazole group (92\%), compared to fluconazole (79\%). Moreover, the occurrence of relapse rate $(4 \%)$ was very low in luliconazole treated patients compared to fluconazole $(20 \%)$ treated patients.

A limitation of this study was that it was a single-centre study with small number of participants. This study was not double blinded as the formulations were contradictory. Perhaps, the additional positive advantage of our study is new molecule luliconazole $1 \%$ cream having the reservoir property in stratum corneum, so the short-term use of topical cream may improve the patient compliance.

\section{CONCLUSION}

In conclusion, the study shows that luliconazole $1 \%$ cream was better and gets faster action to achieve mycological and clinical cure with low incidence $(4 \%)$ of relapse cases, with less adverse events when compared to fluconazole $1 \%$ cream for the treatment of dermatophytosis.

Secondly, short term use of this new molecule luliconazole $1 \%$ topical cream had better advantage and more compatible with patients, in addition to that which improves the rate of patient's compliance.

\section{ACKNOWLEDGEMENTS}

Author would like to thank colleagues and management of Karpaga Vinayaga institute of medical sciences and research centre, Chinnakolambakkam, Kanchipuram District, Tamil Nadu for their contributions to the study.

Funding: No funding sources

Conflict of interest: None declared

Ethical approval: The study was approved by the Institutional Ethics Committee

\section{REFERENCES}

1. Hay RJ, Ashbee HR. Mycology. In: Burns T, Breathnach S, Cox N, Griffiths C, editors. Rook's Textbook of Dermatology. $8^{\text {th }}$ ed. London: WileyBlackwell. 2010;2:36.1.

2. Havlickova B, Czaika VA, Friedrich M. Epidemiological trends in skin mycoses worldwide. Mycoses. 2008;51(4):2-15.

3. Marques SA, Robles AM, Tortorano AM. Mycoses associated with AIDS in the third world. Med Mycol. 2000;38:269-79.

4. Banerjee M, Ghosh AK, Basak S, Das KD, Gangopadhyay N. Comparative evaluation of efficacy and safety of topical fluconazole and clotrimazole in the treatment of tinea corporis. J Pak Asso Dermatol. 2012;22(4).

5. Calvin OM, Thomas JL. Eczema, psoriasis, cutaneous infections, acne and other common skin disorders. In: Fauci, Braunwald, Kasper editors. Harrison's Principles of Internal Medicine. $17^{\text {th }} \mathrm{ed}$. New York: McGraw-Hill. 2008;1:318. 
6. Gupta AK, Sauder DN, Shear NH. Antifungal agents: an overview. Part I. J Am Acad Dermatol. 1994;30(5 Pt 1):677-98.

7. Borgers M. Mechanism of action of antifungal drugs, with special reference to the imidazole derivatives. Rev Infect Dis. 1980;2:520-34.

8. Routt ET, Jim SC, Zeichner JA, Kircik LH. What is new in fungal pharmacotherapeutics? J Drugs Dermatol. 2014;13:391-95.

9. Niwano Y, Kuzuhara N, Kodama H, Yoshida M, Miyazaki T, Yamaguchi H. In vitro and in vivo anti dermatophyte activities of NND-502, a novel optically active imidazole antimycotic agent. Antimicrob Agents Chemothr. 1998;42:967-70.

10. Moriarty B, Hay R, Morris-Jones R. The diagnosis and management of tinea. BMJ. 2012;10;345.

11. Barnetson RS, Marley J, Bullen M. Comparison of one week of oral terbinafine $(250 \mathrm{mg} /$ day $)$ with four weeks of treatment with clotrimazole $1 \%$ cream in inter digital tinea pedis. $\mathrm{Br} \mathrm{J}$ Dermatol. 1998;139:675-8.

12. Valeant Pharmaceuticals Inc. LUZU (luliconazole) Cream, 1\% for topical use. 2013.
13. Subhash B, Khanna D. Luliconazole for the treatment of fungal infections: an evidence-based review. Core Evidence. 2014:9:113-24.

14. Suchil P, Gei FM, Robles M. Once weekly oral dose of fluconazole $150 \mathrm{mg}$ in the treatment of tinea corporis/cruris and cutaneous candidiasis. Clin Exp Dermatol. 1992;17:397-401.

15. Yim SM, Ko JH, Lee YW. To compare the efficacy and safety of fluconazole cream with flutrimazole cream in the treatment of superficial mycosis: a multicentre, randomised, double-blind, phase III trial. Mycoses. 2010;53:522-9.

16. Koga H, Tsuji Y, Inoue K, Kanai K, Majima T, Kasai $\mathrm{T}$ et al. In vitro antifungal activity of luliconazole against clinical isolates from patients with dermatomycoses. J Infect Chemother. 2006;12:1635 .

Cite this article as: Seshathri E, Krishna RD. Comparison of efficacy and safety of topical luliconazole with topical fluconazole against tinea corporis in a tertiary care hospital. Int $\mathbf{J}$ Basic Clin Pharmacol 2021;10:840-5. 